\title{
The Landscape of Social Innovation in Canadian Universities: An Empirical Analysis
}

\author{
Peter Milley \& Barbara Szijarto \\ University of Ottawa \\ Kristen Bennett \\ Independent Researcher
}

\begin{abstract}
There has been global growth in the number of social innovation initiatives launched in the university sector over the last decade. These initiatives aim to address complex social problems and to promote institutional change. This surge is occurring without a well-developed empirical knowledge base. This article provides a comprehensive description and analysis of the landscape of social innovation initiatives in the Canadian university sector. Findings show that nearly half of Canada's 96 universities are associated with at least one initiative; many are interdisciplinary and emphasize collaborative problem-solving with sectors outside the university; and government agencies and charitable foundations are the most common funding sources. Findings suggest there is room for growth and for linking and clustering initiatives. The article concludes with directions for future research.
\end{abstract}

\section{RÉSUMÉ}

La dernière décennie a été marquée par une croissance mondiale du nombre d'initiatives d'innovation sociale lancées dans le secteur universitaire. Ces initiatives visent à résoudre des problèmes sociaux complexes et à induire des changements institutionnels et systémiques. Cette poussée de l'activité d'innovation sociale se produit sans une base de connaissances empiriques bien développée. Nous y contribuons en fournissant une description et une analyse complètes de toutes les initiatives d'innovation sociale auxquelles participe le secteur universitaire canadien, de leurs caractéristiques et du paysage qu'elles constituent. Résultats notables: près de la moitié des 96 universités canadiennes sont associées à au moins une initiative; de nombreuses initiatives sont interdisciplinaires et mettent l'accent sur la résolution de problèmes en collaboration avec des secteurs extérieurs à l'université; Les agences gouvernementales et les fondations caritatives sont les sources de financement les plus courantes. Les résultats suggèrent: il existe un potentiel de croissance de l'innovation sociale dans le secteur; il y a moins de liens internes et de regroupement d'initiatives que ne le recommande la théorie de l'innovation; l'accent mis sur la collaboration extérieure rejoint la «troisième mission» des universités, qui existe depuis longtemps, mais les innovateurs sociaux ont des objectifs, des méthodes et des processus distincts pour mener à bien cette mission. Nous concluons avec les orientations pour les recherches futures. 


\section{Milley, Szijarto, \& Bennett (2020)}

Keywords / Mots clés: Universities; Higher education; Social innovation; Community engagement; Service mission; Social change; Canada / Universités; Établissements d'enseignement supérieur; Innovation sociale; Engagement communautaire; Mission de service; Changement social; Canada

\section{INTRODUCTION}

Over the past decade, a range of actors in the public, private, and not-for-profit sectors have been promoting social innovation as a way to address unmet social needs, find sustainable solutions to complex social problems, and develop a social economy (Adams \& Hess, 2010; European Commission, 2016; McConnell Foundation, 2017a; Mulgan, 2006; NESTA, 2008; Quarter, Mook, \& Armstrong, 2009; Westley \& Antadze, 2010, 2013; White House Office of Social Innovation and Civic Participation, 2016). The growing interest in social innovation has also influenced actors in the higher education sector in Canada and elsewhere, who have subsequently launched a variety of initiatives, such as centres, labs, hubs, projects, programs, and networks focused on fostering social innovation through putatively non-conventional collaborations across disciplines (internally) and sectors (externally) (Ashoka U, 2018a; Baran, Cichocka, Kroczak, \& Maranowski, 2016; Benneworth \& Cunha, 2015; Kanani, 2008; McConnell Foundation, 2017b; Scaled Purpose Inc., 2015; Strandberg, 2017).

By their nature, social innovation initiatives would be expected to challenge and disrupt operating norms, conventional beliefs, and practices inside universities, even as they seek to change or transform society and economy for the better. A small number of international studies (e.g., Baran et al., 2016; Elliot, 2013; Juliani, Silva, Cunha, \& Benneworth, 2017) and only a few Canadian ones (e.g., Nichols, Gaetz, \& Phipps, 2015; Scaled Purpose Inc., 2015) offer empirical insights on how social innovation initiatives develop in universities, what characterizes them, and what influences them. In general, the surge of social innovation activity in Canadian universities is currently taking place without a developed empirical knowledge base to support it. This study was designed to help with the development of empirical foundations for research on social innovation in the sector.

This article reports findings from research on the social innovation landscape in the Canadian university sector. Recognizing that social innovation is a dynamic, relatively new phenomenon, the study's main objective was to provide a systematic description of the current initiatives on the landscape to serve as a baseline for future research and comparisons over time in Canada and with other countries. This work was guided by an overarching question: What characterizes the landscape of social innovation initiatives in Canadian universities in 2018? It focused on three sub-questions: (1) To what extent are Canadian universities involved in social innovation initiatives? (2) What characterizes these initiatives (e.g., goals, activities, maturity)? (3) What patterns are visible on the social innovation landscape (e.g., institutional and geographic concentration, inter-relationships)?

The findings extend and deepen a few notable empirical efforts to describe components of the social innovation landscape, such as Gary Martin, Ann Dale, and Christopher Stoney's (2017) research on Canadian community-based innovation labs, and Scaled Purpose Inc.'s (2015) scan for social innovation hubs in Canadian, American, and European universities. The study also links to a growing international effort to document and analyze the growth of social innovation (e.g., Majewski Anderson, Domanski, \& Howaldt, 2018; SI-DRIVE, 2014).

The next two sections provide context for the study by comparing definitions of social innovation and discussing how it is seen to address challenges in the university sector. The article then offers a description of the study methods, including how the concept of social innovation was operationalized. The findings are then presented along with a discussion regarding their implications for policy and practice. The article closes with comments on the limitations of the study and directions for future research. 


\section{Milley, Szijarto, \& Bennett (2020)}

\section{DEFINING SOCIAL INNOVATION}

Policymakers, expert practitioners, and academics have invested considerable effort in defining social innovation and its characteristics. Numerous conceptualizations have emerged, none of them definitive (Benneworth \& Cunha, 2015; Lorinc, 2017; Westley, 2013). For the moment, social innovation is often presented as a broad paradigm (Stauch, 2016) that encapsulates a range of theories, definitions, and manifestations (Amanatidou, Gagliardi, \& Cox, 2018; Pol \& Ville 2009; TEPSIE, 2014a); however, some common threads are becoming increasingly cohesive. Social innovation is rooted in collaboration, bringing together previously unrelated actors, ideas, practices, programs, or products in new constellations to address social issues and unmet needs (Nichols, Phipps, Provencal, \& Hewitt, 2013; Vorsteveld, 2016; Westley, Goebey, \& Robinson, 2017), frequently with a focus on marginalized groups (European Commission, 2016). The experimental, collaborative processes at the heart of social innovation are deemed to be well-suited to creating adaptive, workable solutions to complex social problems (Bourgon, 2011). Social innovation is seen to be a process-oriented phenomenon, with prominent thinkers presenting it as a sequence of stages or phases (Mulgan, Tucker, Rushanara, \& Sanders, 2007; NESTA, 2014; Westley, Zimmerman, \& Patton, 2006). Social innovation processes are also seen to enhance outcomes by providing a mechanism for the people affected by social issues to take part in co-designing solutions and co-producing outcomes (Boyle, Slay, \& Stephens, 2010; Huddart, 2008; Murray, Caulier-Grice, \& Mulgan, 2010; NESTA, 2008).

In Canada, the influential work of actors associated with the McConnell Foundation and the Social Innovation Generation initiative has advanced a definition that emphasizes systems change. This definition conceives social innovation as an initiative that "challenges and over time contributes to changing the defining routines, resources and authority flows, or beliefs of the broader social system in which it is introduced" (Westley, 2013, p. 2). ${ }^{1}$ This definition uses a complexitydriven perspective that, in its reference to routines, resources, authority, and beliefs, gives prominence to institutional theory (see, for example, Greenwood, Raynard, Kodeh, Micelotta, \& Lounsbury, 2011; Moore \& Westley, 2011). It also incorporates sociotechnical theory in its emphasis on system transformation through cross-scale interactions (Smith, Voß, \& Grin, 2010). In such interactions, innovations initiated at the periphery or in protected "niche" positions lead to changes in broader societal institutions (Geels, 2004).

In sum, by these definitions, social innovation initiatives are thought to work from niche locations in pursuit of broader or multi-level systems change, applying processes that place cross-sectoral and interdisciplinary collaboration at their core, while using previously uncommon methods.

\section{THE CHALLENGE FOR UNIVERSITIES}

In Canada, as elsewhere, stakeholders expect universities to make demonstrable economic and social contributions at regional, national, and international levels (Marginson, 2016). This focus on forging instrumental relationships with economy and society has been intensifying in many countries for over 30 years (Pinheiro, Wangenge-Ouma, Balbachevsky, \& Cai, 2015). At the outset, policymakers and university-based actors concentrated on enhancing direct economic outcomes. Technology transfer and commercialization offices, industrial parks and business incubators emerged on campuses (Bubela \& Caulfield, 2010; Pinheiro et al., 2015), and specialized work-experience programs populated university curricula (Milley \& Kovinthan, 2014). At the same time, some actors were also paying close attention to the social contributions of universities, in particular through the development of community-engaged teaching, research, and service initiatives (Jackson, 2008). However, the drive to increase direct social impacts from universities only came into its own in the early 2000s. This is when social innovation started to garner serious attention (McGowan \& Westley, 2015; Murray et al., 2010; Nicholls \& Murdock, 2012). 


\section{Milley, Szijarto, \& Bennett (2020)}

In Canada, innovation is a key theme in the economic and social development strategies of governments at the federal level, as well as in some provinces. Government policy frameworks position universities as part of innovation ecosystems (Department of Finance Canada, 2016; Government of British Columbia, 2017; Government of Ontario, 2017; Innovation, Science and Economic Development Canada, 2018), and some have led to funding for university-based activities that explicitly target social innovation (Huddart, 2017). Non-governmental actors are also actively trying to position universities for greater social impact through social innovation, with the McConnell Foundation being particularly influential. Starting in 2014, the McConnell Foundation's (2017b) Re-Code initiative provided funding to projects in 37 postsecondary institutions. More recently, the McConnell Foundation (2017c) has been working with senior administrators to determine how to "leverage post-secondary 'social infrastructure' assets (financial, research, educational, relational, physical and social) in service of Canadian communities" (p. 2), with social innovation featuring prominently.

According to its proponents, social innovation also has a role to play in the internal transformation of university systems. Following this perspective, universities are seen to be under pressure to: i) adapt to changing conditions (e.g., student demographics and student mobility, fiscal pressures, global competition, technological change) (Jongbloed, Enders, \& Salerno, 2008; Pinheiro et al., 2015); ii) reposition themselves to better support and integrate with cross-sectoral innovation systems (Benneworth \& Cunha, 2015; Cai, 2017); and iii) to mitigate the negative effects of characteristics associated with mature institutions (e.g., risk-aversion, inflexibility, entrenched professional cultures) (Matheson, 2008; White \& Glickman, 2007). Projects in Canada—such as hackED, an initiative of Re-Code (McConnell Foundation, 2017b)—have launched with the explicit objective of turning the lens of social innovation inward on the university to address these perceived issues.

\section{METHODOLOGICAL APPROACH}

This study was designed to document the landscape of social innovation in Canadian universities at a specific point in time, recognizing the rapid pace of change in this domain. It also explored how actors themselves articulate the character, activities, and purposes of their social innovation initiatives, given the continued lack of consensus among theorists and empirical researchers on the defining characteristics of social innovation (Pol \& Ville, 2009).

\section{Identifying cases}

The cases were chosen by searching the websites of the 96 universities listed as members of Universities Canada (n.d.) to identify social innovation initiatives. To begin with, a broad set of search terms was used to avoid missing valid cases, as metadata vary by site in ways that can affect search results. The terms "social innovation," "social enterprise," "social entrepreneurship," and "social innovation lab" were used for the initial search. A Google search was conducted using the above terms combined with each institution name and the first three pages of results were reviewed. A prospect list was compiled and compared with a list of Re-Code applicants (Vorsteveld, 2016) as a third way to identify prospects.

Specific inclusion criteria were then applied to the prospects to focus the case set on social innovation. The initial prospective case list included 125 initiatives. Data was extracted from information published online about these initiatives. For a subset of 22 ambiguous cases, it was supplemented by primary data collection conducted by phone and email. The researchers discussed all cases in periodic joint sessions to refine the list via the application of inclusion criteria.

\section{Inclusion criteria}

Initiatives were only included if they self-identified with social innovation through the explicit use of the term "social innovation" in their public descriptions. This term was used as an indicator of intentional positioning in this domain. Using explicit self-identification was also important to avoid the scope expanding into other cognate areas, such as community- 


\section{Milley, Szijarto, \& Bennett (2020)}

campus engagement, community-based research, and community-service learning. While the latter bears similarities to social innovation in terms of a commitment to collaboration and service outside the academy, they do not overlap entirely (see concerns expressed by Majewski-Anderson et al., 2018). The study only included initiatives that clearly articulated a social mission (e.g., initiatives that used the term "social innovation" but were focused solely on the creation of for-profit ventures were excluded). In addition, only initiatives that were actively operating in the period of January to April 2018 and were engaged in ongoing activities were included (i.e., initiatives that were limited to one-time events were excluded).

Two other sets of criteria were used for inclusion: 1) a set of criteria for social innovation-related concepts drawn from the literature, and 2) "niche" criteria to indicate potential operation in areas that are novel to universities (see Table 1).

\section{Table 1: Inclusion criteria for cases in sample}

\begin{tabular}{|c|c|}
\hline Category & Description \\
\hline $\begin{array}{l}\text { SI "sounding board" criteria (e.g., } \\
\text { Boyle et al., 2010; Huddart, 2008; } \\
\text { Murray et al., 2010; Svensson et } \\
\text { al., 2018) }\end{array}$ & $\begin{array}{l}\text { The initiative is described in at least one of the following ways: } \\
\text { - Engaging in an innovation process } \\
\text { - Employing experimental, creative, adaptive processes aimed at workable solutions to complex } \\
\text { social problems } \\
\text { - Rooted in collaboration } \\
\text { - Bringing previously unrelated actors, ideas, knowledge, practices, programs, products together to } \\
\text { address social issues } \\
\text { - Encouraging people affected by social issues to take part in co-creation, co-design or co-production }\end{array}$ \\
\hline $\begin{array}{l}\text { "Niche" criteria (Geels, 2004; } \\
\text { Kloet, Hessels, Zweekhorst et al., } \\
\text { 2013) }\end{array}$ & $\begin{array}{l}\text { The initiative is described with at least one of: } \\
\text { - Some level of protection from institutional constraints and pressures (e.g., an external funding } \\
\text { mechanism, external administration) } \\
\text { - Attention to issues that are neglected by traditional academic activities, pursuing unconventional } \\
\text { questions or activities } \\
\text { - The use of unconventional approaches, unconventional alliances }\end{array}$ \\
\hline
\end{tabular}

In keeping with the potential importance of the niche or peripheral positioning of initiatives, cases were included that reported administrative independence from the university, provided that the active participation of the university was evident and explicitly documented on the university's website. In the process of qualifying cases, a number of initiatives that were sub-initiatives or projects of another case were identified in the prospect list. In these instances, only the "parent" initiative, defined as the highest-level entity that was directly engaged in social innovation activities, was retained.

A diverse array of projects and programming falls under the banner of social innovation and definitions of social innovation remain contested, a fact that informed the inclusion criteria. The overall process resulted in the exclusion of 79 prospective cases, or more than half of the original list. At the end of this process, a final list of 46 cases remained (see Table 2).

Table 2: Cases included in sample

\begin{tabular}{|c|c|c|c|}
\hline Initiative & University/Universities & $\begin{array}{l}\text { Province/ } \\
\text { Territory }\end{array}$ & $\begin{array}{l}\text { Launch } \\
\text { year }\end{array}$ \\
\hline Agility Idea Shop & University of Lethbridge & $A B$ & 2016 \\
\hline Centre for Social Innovation and Impact Investing & University of British Columbia & $\mathrm{BC}$ & 2009 \\
\hline
\end{tabular}


Milley, Szijarto, \& Bennett (2020)

Table 2 (continued)

\begin{tabular}{|c|c|c|c|}
\hline Initiative & University/Universities & $\begin{array}{l}\text { Provincel } \\
\text { Territory }\end{array}$ & $\begin{array}{l}\text { Launch } \\
\text { year }\end{array}$ \\
\hline CityLab & McMaster University & ON & 2017 \\
\hline CityStudio & $\begin{array}{l}\text { Simon Fraser University, University of British Columbia, } \\
\text { Emily Carr University of Art + Design }\end{array}$ & $\mathrm{BC}$ & 2011 \\
\hline CLARI - Change Lab Action Research Institute & $\begin{array}{l}\text { Saint Mary's University, Université Sainte-Anne, Cape } \\
\text { Breton University, St. Francis Xavier University, Mount } \\
\text { Saint Vincent University, Acadia University }\end{array}$ & NS & 2016 \\
\hline DESIS Lab & Emily Carr University of Art + Design & $\mathrm{BC}$ & 2012 \\
\hline Discovery University & $\begin{array}{l}\text { Saint Paul University, University of Ottawa, Carleton } \\
\text { University }\end{array}$ & ON & 2005 \\
\hline Extension Innovation and Enterprise Centre & Saint Francis Xavier University & NS & MD \\
\hline Greenhouse & University of Waterloo & ON & 2013 \\
\hline Impact Collective & OCAD University & ON & 2014 \\
\hline Innovate Calgary Social Enterprise Incubator Program & University of Calgary & $A B$ & 2018 \\
\hline Island Sandbox & Cape Breton University & NS & 2014 \\
\hline Jane-Finch Community Impact Hub & York University & ON & 2016 \\
\hline L'Espace Lab & Université du Québec en Abitibi-Témiscamingue & QC & 2018 \\
\hline Libro Social Innovation Program & University of Windsor & ON & 2018 \\
\hline MacEwan Social Innovation Hub (Roundhouse) & MacEwan University & $A B$ & 2018 \\
\hline Maison de l'innovation sociale (MIS) & HEC Montreal, Concordia University & QC & 2017 \\
\hline Making the Shift Youth Homelessness SI Lab & York University & ON & 2017 \\
\hline MaRS Solutions Lab & University of Waterloo & ON & 2013 \\
\hline Mauril-Bélanger Social Innovation Workshop & Saint Paul University & ON & 2018 \\
\hline METIS (Entre Genie et Medecine) & Ecole Polytechnique Montréal & QC & 2010 \\
\hline Northern Innovation Hub & University of Ottawa & ON & 2014 \\
\hline NouLab & University of New Brunswick & NB & 2015 \\
\hline Office of Social Innovation & Ryerson University & ON & 2016 \\
\hline Quartier de l'innovation (Ql) & $\begin{array}{l}\text { École de technologie supérieure, McGill University, } \\
\text { Concordia University, Université du Québec à Montréal }\end{array}$ & QC & 2013 \\
\hline RADIUS (RADical Ideas Useful to Society) & Simon Fraser University & $\mathrm{BC}$ & 2013 \\
\hline
\end{tabular}


Milley, Szijarto, \& Bennett (2020)

Table 2 (continued)

\begin{tabular}{|c|c|c|c|}
\hline Initiative & University/Universities & $\begin{array}{l}\text { Provincel } \\
\text { Territory }\end{array}$ & $\begin{array}{l}\text { Launch } \\
\text { year }\end{array}$ \\
\hline Schlegel Centre for Entrepreneurship and SI & Wilfrid Laurier University & ON & 2017 \\
\hline Slx & Carleton University & ON & 2017 \\
\hline Skills Society Citizen Action Lab & University of Alberta & $A B$ & 2016 \\
\hline $\begin{array}{l}\text { Social Enterprise and Entrepreneurship, Northern } \\
\text { Region Partnership }\end{array}$ & Algoma University & ON & 2014 \\
\hline Social Innovators' Integration Lab & McGill University, Carleton University & QC, ON & 2016 \\
\hline Social Learning for Social Impact GROOC & McGill University & QC & 2015 \\
\hline Social Ventures Zone & Ryerson University & ON & 2014 \\
\hline SparkZone & $\begin{array}{l}\text { Saint Mary's University, Mount Saint Vincent University, } \\
\text { NSCAD University }\end{array}$ & NS & 2014 \\
\hline Strategic Innovation Lab & OCAD University & ON & 2008 \\
\hline Sustain $X$ & University of Alberta & $A B$ & 2016 \\
\hline The Guelph Lab & University of Guelph & ON & 2015 \\
\hline Trico Changemakers Studio & Mount Royal University & $A B$ & 2018 \\
\hline Tswassen Farm School & Kwantlen Polytechnic University & $\mathrm{BC}$ & 2015 \\
\hline Ulab Social Innovation Hub & Concordia University & QC & 2016 \\
\hline Vancouver Island Social Innovation Zone & Royal Roads University, University of Victoria & $\mathrm{BC}$ & 2016 \\
\hline Vivacity & $\begin{array}{l}\text { Mount Royal University, University of Calgary, University } \\
\text { of Lethbridge }\end{array}$ & $A B$ & 2013 \\
\hline Winnipeg Boldness & University of Manitoba, University of Winnipeg & MB & 2014 \\
\hline Waterloo Institute for Social Innovation and Resilience & University of Waterloo & ON & 2010 \\
\hline SHIFT & Concordia University, Université du Québec à Montréal & ON & 2018 \\
\hline
\end{tabular}

\section{Characteristics of the data}

For each case, data was extracted to structured case sheets using a preset Microsoft Word template. These data included qualitative text extracts (e.g., a mission statement); categorical data (e.g., the types of funding reported, the types of activities, disciplinary affiliation); and other attributes (e.g., launch year). Selected web pages were also collected for each initiative (e.g., pages stating the initiative's mission and purpose, pages describing activities and projects, and pages listing contact information and the people involved). A total of 375 pages were compiled. 


\section{Analysis}

Categorical and quantitative case data was organized in a Microsoft Excel matrix for descriptive statistical analysis. Qualitative data was coded and analyzed in NVivo. Two team members coded the qualitative data independently following a preset framework and met at intervals to compare results. Differences in coding results were discussed with reference to coding definitions. A subset of cases that presented challenges to consensus was revisited at the end of the process and compared against "archetype" cases to ensure coding accuracy. All results were reviewed and discussed as a team at key points during analysis, at times prompting a return to the raw data to resolve ambiguities, until consensus was reached.

\section{FINDINGS}

The findings are organized by the three sub-questions guiding the study.

\section{Research question 1: To what extent are Canadian universities involved in social innovation initiatives?}

Forty-one of Canada's 96 universities were found to be involved in at least one social innovation initiative, as defined by the study's criteria. This represents close to half ( $43 \%)$ of the universities. Of those 41 , most (21) were involved with a single initiative, and some (16) were involved with two. Only a few (4) were engaged with more than two initiatives (see Figure 1).

\section{Figure 1: SI initiatives per university}

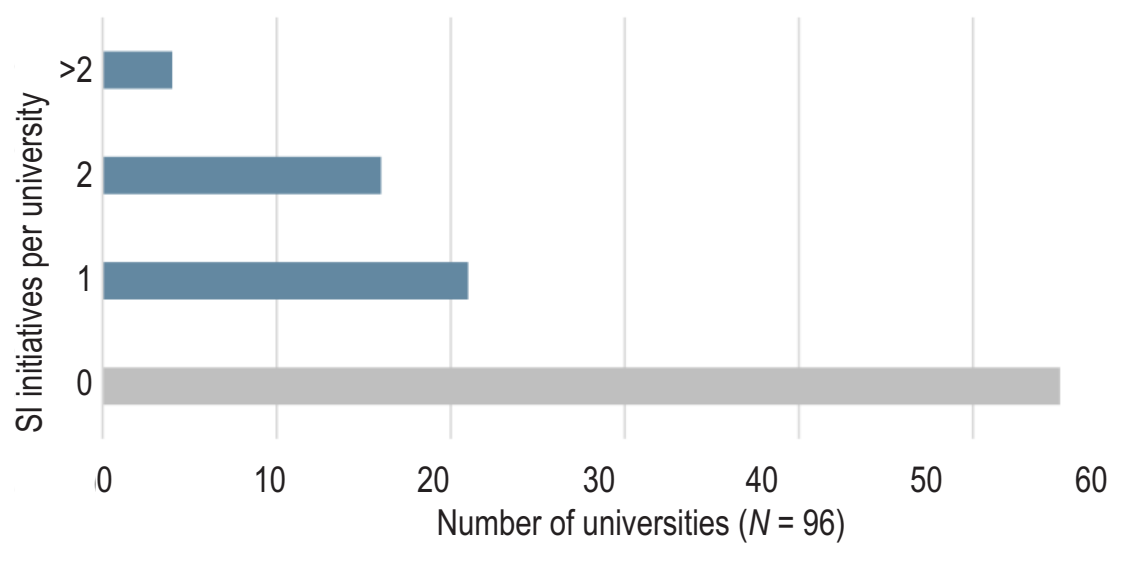

Overall, there was less penetration of social innovation within institutions and less spread across the sector than might be expected, given the internationally recognized level of social innovation activity in Canada more generally (Kondo, 2016). There appears to remain substantial room for growth. ${ }^{2}$

\section{Research question 2: What characterizes social innovation in Canadian universities?}

The initiatives in the study's set of cases were striking for their youth and interdisciplinary character. They also reported a diverse set of activities and focus areas.

Youth

The majority (84\%) of the initiatives had launched within the previous five years (see Figure 2). More than a quarter of the initiatives in the case list $(27 \%)$ had launched within the previous 16 months. Likely explanations for this pattern include attrition, recent targeted funding and policy orientations, and the reorientation of older initiatives. In terms of attrition, there is some evidence in the initial search data of initiatives failing after five years. In addition, the initial prospect list identified several older initiatives that had ceased activities and were, therefore, excluded from the case set. The 


\section{Milley, Szijarto, \& Bennett (2020)}

most high profile among these was the Social Innovation Generation project associated with the University of Waterloo (Cahill \& Spitz, 2017). Another likely contributor is the intensified interest and availability of funding in Canada in the five years leading up to data collection, the most notable being the McConnell Foundation's Re-Code project (2017b). Lastly, there may be some "rebranding" or "morphing" of older initiatives to encompass social innovation. An example is the reorientation of the Schlegel Centre at Wilfrid Laurier University, which was relaunched to include "for entrepreneurship and social innovation" in its name in $2016 .^{3}$

Figure 2: Number of initiatives by year launched

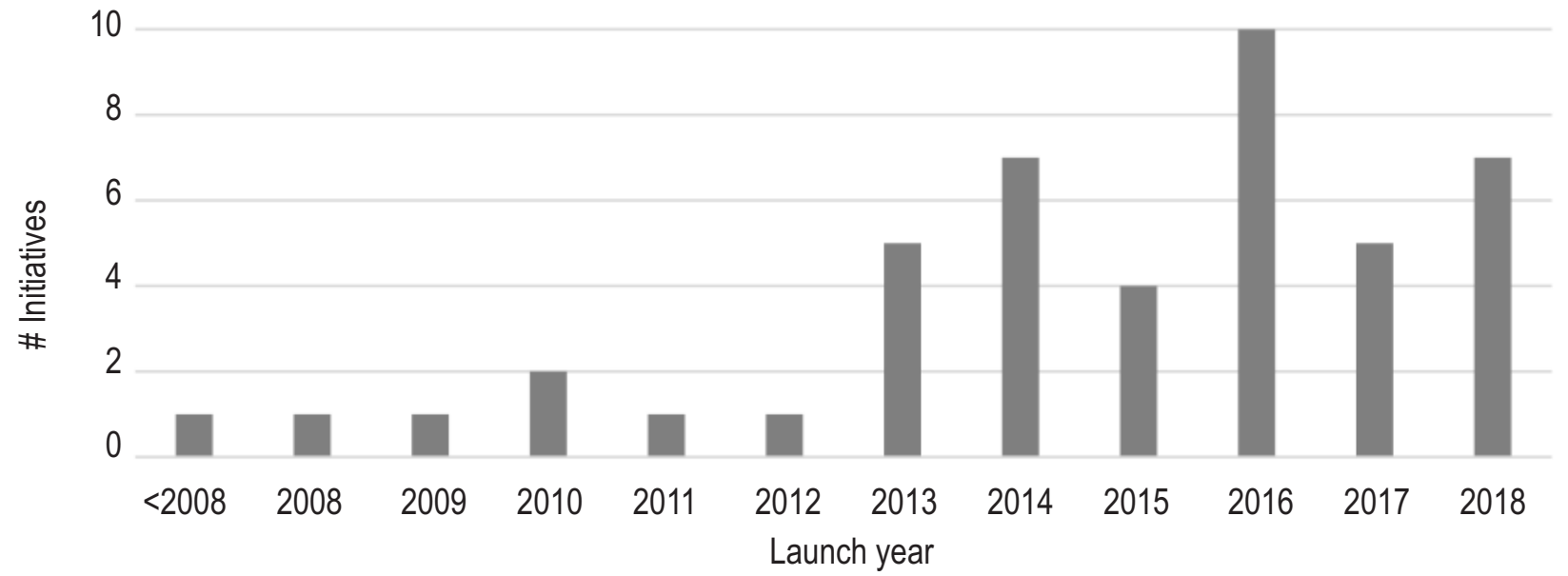

Interdisciplinarity and disciplinary (non)affiliation

There was no evidence of the concentration of social innovation activity in any particular discipline. Most of the initiatives (65\%) either did not report a specific faculty or disciplinary affiliation, or described themselves as interdisciplinary. For example, the Centre for Social Enterprise at Memorial University (2018) is a collaboration between the School of Music, the School of Social Work, and the Faculty of Business Administration. Of those explicitly connected to a single discipline or faculty, eight were located in schools of business or management, four in faculties of arts and science, and four in another faculty (e.g., engineering, environment). A noteworthy minority of cases (20\%) is administered by an organization or entity outside of the university. Examples include CityLab, CityStudio, and Winnipeg Boldness. One case, the Guelph Lab (University of Guelph, n.d.), is jointly administered by the university and the local municipality. The case data indicate diversity with respect to where the initiatives originated. Some were initiated by individual groups of actors at the "grassroots" level. Others were sponsored by central administration, i.e., as part of an institutional-level strategy.

In sum, there appears to be significant diversity with respect to the location of initiatives within higher education institutions. These findings are consistent with observations by others (e.g., Kanani, 2016) that interest in social innovation has spread across multiple disciplines from an early concentration in business schools. It is also consistent with the assertion that social innovation initiatives draw on and promote interdisciplinarity (TEPSIE, 2014b). The issue of location relative to the university's central administration is revisited below in the discussion regarding questions for future research.

\section{Activities}

The activities and services offered through the initiatives were recorded. Through an iterative coding process, 13 types of common activities were found across multiple cases. Nearly all cases (93\%) reported carrying out more than one type of activity, with an average of five per initiative. These 13 types were grouped under four thematic categories: fostering collaboration or engagement; training, mentoring, and capacity building; new venture support; and academic research. ${ }^{4}$ 
Table 3 lists the activities identified and the number of initiatives that reported engaging in each one..$^{5}$ Overall, there was a heavy emphasis on fostering collaboration and/or engagement outside the university. Nearly all cases (91\%) reported activities in this category. In particular, 65 percent of the cases described linking and brokering activities, for example, developing networks to connect people, resources, and ideas. About half $(52 \%)$ reported providing a physical space for direct collaboration, usually described as a lab space.

Table 3: Types of activities and number of initiatives engaging in each type

\begin{tabular}{|l|c|}
\hline Activity Category/Type & \# of Initiatives \\
\hline Fostering Collaboration or Engagement & 42 \\
\hline Linking and brokering (e.g., network development; connecting people, resources, and ideas) & 30 \\
\hline Space for collaboration (e.g., providing a dedicated lab space, a "collision space") & 24 \\
\hline "Real-life" project collaboration (e.g., design thinking, co-production, prototyping solutions, implementing projects) & 21 \\
\hline Applied/community-engaged research collaborations & 16 \\
\hline Hosting events (e.g., issue-based forums and exchanges) & 13 \\
\hline Training, Mentoring, Capacity Building & 37 \\
\hline $\begin{array}{l}\text { Programming to build capacity for social innovation/social enterprise (e.g., workshops, coaching for a variety of actors, } \\
\text { including outside the university) }\end{array}$ & 24 \\
\hline Academic programming (e.g., courses, certificates, experiential learning for enrolled students) & 22 \\
\hline Mentoring and advisory services (e.g., one-on-one advice and support) & 18 \\
\hline New Venture Support & 23 \\
\hline Incubation/acceleration of new ventures & 18 \\
\hline Competitions & 10 \\
\hline Seed funding & 10 \\
\hline Academic Research About SI & 9 \\
\hline Academic research and/or evaluation studies on SI and/or SE (e.g., SI theory-building, "what works" studies) & 8 \\
\hline Knowledge mobilization, the dissemination of research about SI and/or SE & 4 \\
\hline
\end{tabular}

The second most common overall category was training, mentoring, and capacity building. A strong majority of initiatives $(80 \%)$ reported activities in this category, particularly programming to build capacity for actors to engage in social innovation work (e.g., offering workshops or coaching to non-university-based individuals or groups).

The third most common category was support to new social ventures (e.g., social enterprise incubation). Half of the cases described activities to accelerate the creation or launch of new ventures. This is not so surprising, since in spite of their different roots, cross-pollination between social innovation, social enterprise, and social entrepreneurship is well documented (Cunha, Benneworth, \& Oliveira, 2015; Szijarto, Milley, Svensson, \& Cousins, 2018). In recognition of this, the case data was searched for the explicit use of the terms "social enterprise" and "social entrepreneurship" to determine how many of the cases used them. As noted above, all of the cases in the set used the term "social innovation." In 


\section{Milley, Szijarto, \& Bennett (2020)}

addition, 33 percent referred to social entrepreneurship, 28 percent to social enterprise, and 15 percent used both terms. Scholars recognize these two terms tend to be nested within the social innovation lexicon or used interchangeably with the term social innovation; yet they are also distinct concepts (Cunha et al. 2015; Szijarto et al., 2018). Social enterprise describes a specific organizational structure or is sometimes used to refer to a hybridized set of organizational features, such as the use of business methods and joint economic and social aims (see, for example, Antadze \& Westley, 2012; Cunha et al., 2015). Social enterprises depart from other social innovation initiatives in ways linked with identity, as well as structure and methods (Szijarto et al., 2018). Social entrepreneurship is also a concept with its own features, connected to its agent or actor-driven focus and its own "distinct intellectual heritage" relative to social innovation (Cunha et al., 2015 p. 2). Yet, the three concepts nonetheless have a social mission in common, and this study's empirical data reflect their intermixing in the field of practice, despite scholarly debate at the conceptual level.

\section{Focus areas}

Fewer than half of the cases (43\%) identified a particular substantive focus or topic area for the initiative, such as a specific population (e.g., individuals who are homeless) or problem area (e.g., the environment). The remaining initiatives $(57 \%)$ tended to describe activities aimed broadly at systemic or social change but did not reference predetermined areas of focus. Some members of this second group described an intention to allow foci to remain open until determined through a process (e.g., dialogue with community stakeholders).

Among the cases that reported a substantive focus, half identified a single focal issue (e.g., climate change). The other half reported two or more issues of interest. The diversity of issues identified in these data is striking; 14 were identified among these 20 cases. The most common related to environmental issues. Half of the initiatives (10) reported some focus of this nature (e.g., environmental sustainability, clean technology, climate change resilience). The next most reported topics were local development (e.g., healthy neighbourhoods, local culture and heritage, municipal excellence) and poverty/inequality. Other topics included alternative economics, health/mental health, youth, new Canadians, Indigenous Peoples, persons who are homeless, food security, violence prevention, persons with disabilities, and education outside universities. All these foci pertain to issues outside of the university, and the emphasis is mostly local or regional.

Among initiatives that did not target specific social issues, several expressed openness to diverse foci, with open-ended collaboration and/or open-space engagement with stakeholders serving as a means to identify and define issues for attention. The presence of both issue-directed and co-creative approaches corresponds with the ways in which social innovation is being pursued in other sectors and internationally, where it develops both from problem-recognition and through discovery and incubation processes in hubs, labs, and other open-space environments (TEPSIE, 2014b). The diversity afforded by a landscape for social innovation that accommodates multiple origins, foci, and activities (along with interdisciplinarity) is understood to be a strength (Cameron, 2012; Mulgan, 2012; TEPSIE, 2014b).

Overall, however, there was a minimal emphasis on innovation, disruption, or change inside universities. This is surprising because the literature has identified conventional institutional structures and norms as impediments to social change through social innovation (Cameron, 2012; Moore \& Westley, 2011). This is revisited in the discussion below.

\section{Research question 3: What characterizes the overall social innovation landscape?}

The third research question focused on relationships in the landscape. This study reports on three types of relationships: those with other universities, those with other non-university organizations, and funding relationships.

Relationships with universities

Only about one quarter of the initiatives $(24 \%)$ reported formal relationships with more than one university. Those that in- 


\section{Milley, Szijarto, \& Bennett (2020)}

volved multiple universities were almost all geographically defined, with collaborations between institutions located in the same urban area or region. Such collaborations involved between two and six universities (three on average).

Some observers call for the clustering and linking of innovations and innovators to advance social innovation (e.g., Mulgan, 2006, 2012). Although, the data does not strongly evidence this dynamic in terms of formal relationships, research revealed informal networks emerging in the sector, such as Converge: Canadian Lab Practitioners Exchange (RADIUS, 2018), a Canadian Network Day at Ashoka Changemaker Showcase events (Ashoka U, 2018b), and the recent emergence of Social Innovation Canada (2019) as a national networking organization. Paul Benneworth and Jorge Cunha (2015) argue that a tension exists between the competitive operational environment in universities and the collaborative nature of social innovation. This may be one factor influencing patterns of formal collaboration. This notion is revisited below in the discussion about an agenda for research.

Non-university relationships

Although only 24 percent of initiatives reported collaborating with multiple universities, most (83\%) reported a relationship with at least one other external organization, such as a government agency, foundation, not-for-profit agency, or private sector company. The most commonly reported non-university relationship was with government ( $57 \%$ of cases), followed closely by foundations (52\%) and not-for-profit agencies (52\%). Fewer than half of the initiatives (41\%) reported formal relationships with the private sector.

The number and diversity of reported relationships vary widely. A few initiatives reported none, while others reported extensive and diverse ties with, for example, small local businesses as well as national agencies, and across multiple sectors. Linkages were reported both at the organizational level (e.g., funding relationships as described below) and via individual actors (e.g., advisory board members for Winnipeg Boldness, who connect with 16 other organizations).

More than a quarter $(28 \%)$ of the initiatives in the set named the McConnell Foundation, making it by far the single most identified organization-level relationship. One third (33\%) of the cases reported a connection with a bank or a credit union. Other organizations identified by multiple cases are Ashoka Changemakers (three initiatives), Enactus (three), MaRS (three), Social Innovation Generation (three), and chapters of the United Way (three). No single government agency at any level stood out across the cases; however, eleven initiatives $(24 \%)$ reported a relationship with their local municipal government. Overall, relationships were strongly local or regional, consistent with the foci of many initiatives on local or regional issues (as noted above). This pattern also accords with how universities have been viewed and treated as engines of local and regional economic development (Bramwell \& Wolfe, 2008; Doutriaux, 1998). In general, these data suggest a fragmented landscape, with the McConnell Foundation currently the key "outside" actor on the landscape by a wide margin.

\section{Funding relationships}

Most initiatives (67\%) publicly recognized at least one source of funding (see Figure 3), and of these, a majority (58\%) reported multiple types (e.g., both foundation and private sector funding). The most commonly reported funding source was a foundation (53\% of the initiatives). Private sector funding sources followed: $48 \%$ of the initiatives that reported funding relationships included at least one from the private sector. The data revealed less private sector involvement than was anticipated in light of the focus on social enterprise and entrepreneurship as key areas of activity in nearly half of these initiatives.

Municipalities were the least commonly reported government funders, and equal to funding from individual private citizens. Nevertheless, there is broad taxpayer investment in university-linked social innovation initiatives. When levels of govern- 
ment are combined (federal, provincial, and municipal), this becomes the most common funding source: 81 percent of cases identified a government funder at some level.

Figure 3: Funding sources by percentage of initiatives reporting

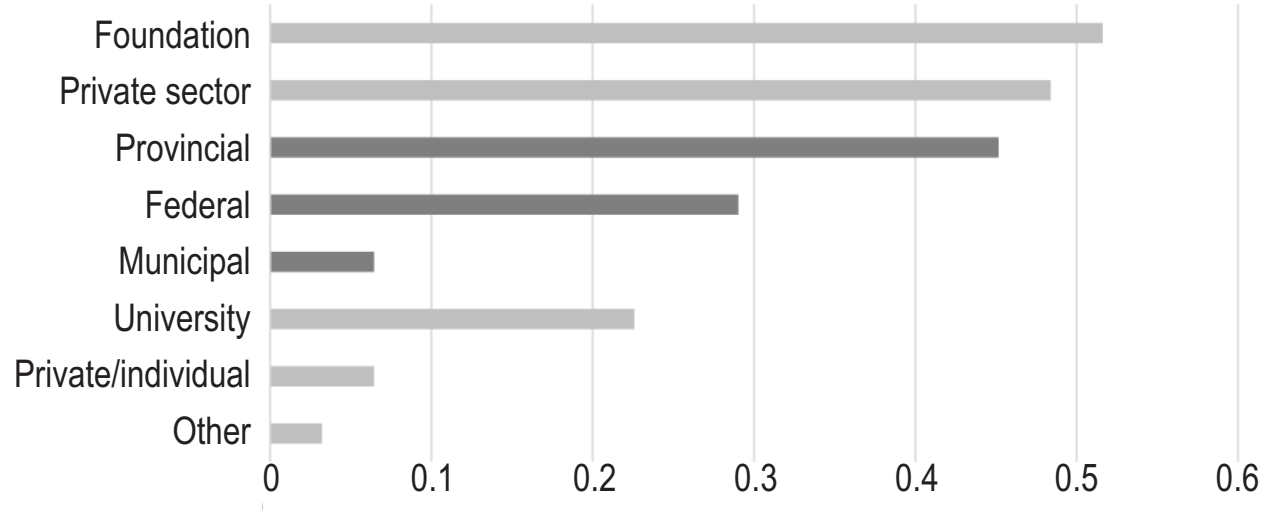

More initiatives reported support from a provincial government than the federal government. This is not surprising, as education falls under provincial authority in Canada. Fewer identified ties with the federal government might also relate to the absence of a federal social innovation strategy at the time of data collection (Employment and Social Development Canada, 2018a). Such a strategy has been under development, and the advisory council for it includes actors associated with university-based social innovation initiatives (Employment and Social Development Canada, 2018b). Additional involvement of the federal government in university-based social innovation seems plausible in the near future.

\section{DISCUSSION AND CONCLUDING REMARKS ON FUTURE RESEARCH}

These findings highlight the diversity among social innovation initiatives in Canadian universities, particularly with respect to their interdisciplinarity, the types of activities they undertake, their areas of focus, and their partnerships. Yet the cases also exhibit common features. They tend to be young, regionally or locally oriented, and mainly focused outward to address social issues beyond the university.

Numerous activities were identified at the heart of the work of these initiatives. Activities spanned the types of support proposed by Benneworth and Cunha (2015) with which universities might contribute to social innovation, namely providing and brokering knowledge and contributing material resources (such as physical space) and know-how (such as mentorship and advice on innovation processes).

The majority of initiatives aim to foster collaboration or engagement between actors inside and outside of the university to address social issues. This intersects with the long-standing "third mission" - the duty to service-of modern universities (Jongbloed et al., 2008) and with what some actors in university communities have been doing for many years through, for example, joint training or research projects that bring together the academic community with actors from other sectors via community service learning (Hall, 2009), community campus engagement (Weerts \& Sandmann, 2010), or community-based research (Wallerstein \& Duran, 2008). Yet, based on their self-descriptions, the social innovation initiatives in this data set differentiate themselves from these longer-standing approaches. Specifically, they offer alternative conceptual and methodological frameworks, and unconventional practice-level structures and processes (Boyle et al., 2010; Murray et al., 2010; Nichols et al., 2013; Westley et al., 2017). For example, organizational forms such as hubs and labs, conceptual inputs such as innovation process theory, and methods such as design thinking feature prominently in the data. The difference between social innovation and other community-campus engagement initiatives seems most visible in how the former describe how they carry out their activities, particularly with respect to experimentation and iteration, the 


\section{Milley, Szijarto, \& Bennett (2020)}

intensity of collaboration, direct intervention in problems using a systems-thinking mindset, and the use of ideas and models from the business community, such as social entrepreneurship and enterprise.

Most of the initiatives included in this study are also engaged in training, mentoring, and capacity building activities. This category has an educational focus and, thus, builds on the core functions and competences of university communities. In addition, half of the initiatives support the launch of social enterprises, which fits with role of universities as key players in innovation ecosystems (Jongbloed et al., 2008) and builds on the role universities have played in supporting other forms of entrepreneurship and venture creation through schools of business, university extension activities, and, more recently, technology transfer and commercialization offices. As above, what differentiates social innovation from these latter activities is how social innovation initiatives describe how they carry out their work and their focus on social change and impact.

An empirically based typology for social innovation proposed by Maria Rabadijeva, Antonius Schröder, and Marthe Zirngiebl (2017) is relevant to these findings. This typology includes four types: repairing, modernizing, transforming, and separating. Repairing and modernizing types focus primarily on improving, fixing, or extending existing offerings (e.g., adding the remote delivery of services via a new technology) but leave the "system's core identity untouched" (p. 87). The transforming type seeks more fundamental system-level change. Members of the separating type operate in parallel, at times in competition with incumbents and may ultimately replace them. In a similar way, Yuzhuo Cai (2017) draws on the work of Clayton Christensen and Henry Eyring (2011) to describe two types of innovations in universities: "disrupting" or "sustaining" (p. 597). The former threatens university traditions, while the latter does not. In this case data, most reported activities are consistent with the core functions of the university, some extend them but few appear to depart fundamentally. They were overwhelmingly oriented to change outside the institution.

\section{The importance of conceptual clarity}

Because many definitions of social innovation exist, it might be expected that social innovation in universities would articulate the character, activities, and purpose of their initiatives in a variety of ways. In the sample within this study, some initiatives offered clear and nuanced characterizations of their work, while others provided limited information or information that was ambiguously worded.

Ambiguity is a concern if it indicates underdeveloped thinking about what the initiative does and why, and its role relative to other university programming. This has implications for an initiative's development and sustainability. Ambiguity also presents obstacles for outside actors to understand the initiative, including funders, policymakers, and potential participants. ${ }^{6}$ Previous research (i.e., Svensson, Szijarto, Milley, \& Cousins, 2018) shows that there is confusion in other sectors about what constitutes social innovations versus conventional projects or programs. A lack of clarity may even lead skeptics to perceive social innovation initiatives as a mere rebranding of established areas of practice to enhance the image of the program or institution.

Intermediary organizations active in social innovation in the university sector (e.g., Ashoka U, Enactus, McConnell Foundation) are providing an interpretive function for outsiders who are trying to make sense of this field. These intermediaries are likely to help shape what social innovation is understood to be and what it becomes, alongside policy and funding bodies. There is a role here for social innovation practitioners to ensure that their voices are clearly heard. There is also a role for researchers to track developments and return what they learn to practitioners, policymakers, and funders. The next section addresses an agenda for research, after noting some limitations of the present study.

\section{Limitations}

This study was intended to provide an exploratory, descriptive scan of the terrain during a defined time period. The study's 


\section{Milley, Szijarto, \& Bennett (2020)}

scope and design carry limitations. In particular, it relied largely on publicly available information, self-published by the initiatives and their associated universities. Consequently, the results reflect how the initiatives describe themselves and their work to a public audience.

Moreover, while the inclusion criteria were intended to maintain a clear focus on the phenomenon of interest, the resulting case set may understate the influence of social innovation in the university sector. More may be going on informally or may be falling under different terms than the ones used here.

Part of the challenge for a study of this type is the rapid change in this field. During the search process, the initiatives went through numerous changes: rebranding and reorganizing; initiatives being launched and retired; new staff, strategies, activities, and partnerships; changing web content; and shifts in approaches to participation in the social innovation domain from major actors (e.g., the termination of a major funding program). This added to the challenges of case qualification and the subsequent analysis of the set.

\section{Agenda for research}

This study raised numerous questions about the future of social innovation in higher education. Four areas of inquiry seem especially deserving of attention.

First, there was very little mention in the data about explicit objectives for fundamental change within the university system or institutional renewal. In-depth case study work is needed to better understand the range and variety of objectives and the degree to which outward-facing initiatives may (or may not) influence internal innovation. For example, it has been proposed that engagement with social innovation might fundamentally change the nature of teaching in universities (Benneworth \& Cunha, 2015). A study to trace such processes is becoming viable with the extent of the uptake and duration of engagement in social innovation by universities.

Second, given that collaboration is at the heart of social innovation, what it looks like and how it functions in practice is an important question. At a landscape level, very few formal linkages were found between initiatives and there was little cross-institutional clustering. There is likely to be more interaction than indicated in the data. Social network analysis may be a worthwhile means to better understand the formal and informal patterns of collaboration and what may influence them. This type of study would offer a baseline for comparison over time.

Third, the empirical evidence base for claims made about the contributions and impacts of social innovation, whether outside or inside universities, remains limited (TEPSIE, 2014a). Critical questions have been raised in this respect, for example, on community innovation labs (Martin, Dale \& Stoney, 2017). Fortunately, there is a growing knowledge base on how to assess and evaluate social innovations, given their unique purposes, features, and processes (see e.g., Antadze \& Westley, 2012; Fischer \& Richter, 2017; Milley, Szijarto, Svensson, \& Cousins, 2018; Patton 2011; Preskill \& Beer, 2010; Svensson, Szijarto, Milley, \& Cousins, 2018; Vo \& Christie, 2018). Those asking evaluative questions (and those subject to such questions) should be encouraged to explore, learn from, and advance that body of work, so that approaches taken to evaluation can be "fit for purpose."

Finally, there are now many practitioners with experience operationalizing ideas associated with social innovation in universities. Empirical description drawing on their experiences could help bring clarity about how social innovation is practiced. Such research could investigate how these actors translate the "ideal" of social innovation into practice, and the ways in which practice can advance social innovation theory. 


\section{Milley, Szijarto, \& Bennett (2020)}

Social innovation is still a young field of practice and research. Ultimately, whether and how it will influence universities and their host communities and societies remains an open question.

\section{ACKNOWLEDGEMENT}

This article draws on research supported by the Social Sciences and Humanities Research Council and by the Faculty of Education and Centre for Research on Educational and Community Services at the University of Ottawa.

\section{NOTES}

1. In the U.K. and Europe, the early work of Geoff Mulgan (2006) and various actors associated with The Young Foundation (2012), NESTA (2008), Social Innovation Exchange (2018), and the European Commission (2016) has had a significant influence. This work draws from innovation strategy and process, social economy and movements, and social enterprise perspectives. This results in definitions that emphasize the invention of new products, processes, models, and organizational entities, while emphasizing collaboration and interaction to produce social capital.

2. Seventeen cases in other universities that reflected an interest in social innovation were excluded because they did not meet the inclusion criteria.

3. These influencing factors are likely to be interrelated. For example, the degree to which funders and policymakers emphasize new initiatives or projects may incentivize new launches or rebranding. The extent to which they emphasize specific and tangible "quick returns" from social innovation over capacity building for social innovation is also likely to affect the sustainability of the initiatives (Benneworth \& Cunha, 2015). As an example, see the Natural Sciences and Engineering Research Council's (2019) College and Community Innovation program.

4. Some activities, such as research about social innovation, would not by themselves have qualified the case for this study; however, to provide a more complete picture of the full range of activities, initiatives where research activities co-existed with other activities were included.

5. This data is based on self-reporting via the initiatives' online content. For this reason, the findings about activities are most useful for understanding a relative emphasis in types of activities across cases.

6. Jessica Vorsteveld (2016) noted similarly unclear language in a study of strategies for social innovation and social enterprise programming at Canadian universities.

\section{WEBSITES}

Ashoka Changemakers, https://www.ashoka.org/en-ca/program/ashoka-changemakers

Centre for Social Enterprise at Memorial University, https://www.mun.ca/socialenterprise

CityLab, https://www.citylab.com

CityStudio, https://citystudiovancouver.com

Enactus, https://enactus.org

MaRS, https://www.marsdd.com

McConnell Foundation, https://mcconnellfoundation.ca

Social Innovation Generation, http://www.sigeneration.ca

United Way, http://unitedway.ca

Winnipeg Boldness Project, https://www.winnipegboldness.ca

\section{REFERENCES}

Adams, D., \& Hess, M. (2010). Social innovation and why it has policy significance. The Economic and Labour Relations Review, 21(2), 139-155. 


\section{Milley, Szijarto, \& Bennett (2020)}

Amanatidou, E., Gagliardi, D., \& Cox, D. (2018). Social engagement: Towards a typology of social innovation [Working paper]. MIOIR/MBS Working paper series. URL: https://www.research.manchester.ac.uk/portal/files/66664922 /MIOIRWP82_SI_AmanatidouetalMar2018_1_.pdf [September 25, 2018].

Antadze, N., \& Westley, F.R. (2012). Impact metrics for social innovation: Barriers or bridges to radical change? Journal of Social Entrepreneurship, 3(2), 133-150.

Ashoka, U. (2018a). What we do. Ashoka. URL: http://ashokau.org/about/what-we-do/ [September 25, 2018].

Ashoka, U. (2018b). Ashoka Canada: About. Ashoka. URL: https://www.ashoka.org/en/country/canada [September 25, 2018].

Baran, M., Cichocka, E. Kroczak, H., \& Maranowski, P. (2016). Analysis of the involvement of higher education institutions from selected Central European countries in the process of creating, implementing and supporting social innovation. URL: https://www.civitas.edu.pl/collegium/wp-content/uploads/2015/12/SOCIAL_INNOVATION _IN-_HIGHER-_EDUCATION_IN_CENTRAL_EUROPE_REPORT_FULL.pdf [November 7, 2018].

Benneworth, P., \& Cunha, J. (2015). Universities' contributions to social innovation: Reflections in theory and practice. European Journal of Innovation Management, 18(4), 508-527.

Bourgon, J. (2011). A new synthesis of public administration: Serving in the 21st century. Montréal, QC, \& Kingston, ON: McGill Queens Press.

Boyle, D., Slay, J., \& Stephens, L. (2010). Public services inside out: Putting co-production into practice. London, UK: New Economics Foundation.

Bramwell, A., \& Wolfe, D.A. (2008). Universities and regional economic development: The entrepreneurial University of Waterloo. Research Policy, 37(8), 1175-1187.

Bubela, T.M., \& Caulfield, T. (2010). Role and reality: Technology transfer at Canadian universities. Trends in Biotechnology, 28(9), 447-451.

Cahill, G., \& Spitz, K. (2017). Social innovation generation: Fostering a Canadian ecosystem for systems change. SiG. URL: https://www.thesigstory.ca/ [September 25, 2018].

Cai, Y. (2017). From an analytical framework for understanding the innovation process in higher education to an emerging research field of innovations in higher education. Review of Higher Education, 40(4), 585-616.

Cameron, H. (2012). Social entrepreneurs in the social innovation ecosystem. In A. Nicholls \& A. Murdock (Eds.), Social innovation: Blurring boundaries to reconfigure markets (pp. 199-220). Basingstoke, UK: Palgrave Macmillan.

Christensen, C.M., \& Eyring, H.J. (2011). The innovative university: Changing the DNA of higher education from the inside out. San Francisco, CA: Jossey-Bass.

Cunha, J., Benneworth, P., \& Oliveira, P. (2015). Social entrepreneurship and social innovation: A conceptual distinction. In L. Farinha, J.M Ferreira, H. Lawton Smith, \& S. Bagchi-Sen, (Eds.), Handbook of research on global competitive advantage through innovation and entrepreneurship (pp. 616-639). Hershey, PA: IGI Global.

Department of Finance Canada. (2016). Strengthening innovation networks and clusters. Growing the middle class. URL: http://www.budget.gc.ca/2016/docs/plan/budget2016-en.pdf [September 25, 2018].

Doutriaux, J. (1998). Canadian science parks, universities, and regional development. In J. de la Mothe \& G. Paquet (Eds.), Local and regional systems of innovation (pp. 303-325). New York, NY: Springer.

Elliott, G. (2013). Character and impact of social innovation in higher education. International Journal of Continuing Education and Lifelong Learning, 5(2), 71-84.

Employment and Social Development Canada. (2018a). Social innovation and social finance. URL: https://www.canada .ca/en/employment-social-development/programs/social-innovation-social-finance.html [September 25, 2018].

Employment and Social Development Canada. (2018b). Biographies of the members of the Social Innovation and Social Finance Strategy Co-Creation Steering Group. URL: https://www.canada.ca/en/employment-social-development /programs/social-innovation-social-finance/steering-group/member-biographies.html [September 25, 2018].

European Commission. (2016). Social innovation. URL: https://ec.europa.eu/growth/industry/innovation/policy/social _en [July 5, 2016]. 


\section{Milley, Szijarto, \& Bennett (2020)}

Fischer, R.L., \& Richter, F. (2017). SROI in the pay for success context: Are they at odds? Evaluation and Program Planning, 64, 105-109.

Geels, F.W. (2004). From sectoral systems of innovation to socio-technical systems: Insights about dynamics and change from sociology and institutional theory. Research Policy, 33(6), 897-920.

Greenwood, R., Raynard, M., Kodeh, F., Micelotta, E., \& Lounsbury, M. (2011). Institutional complexity and organizational responses. The Academy of Management Annals, 5(1), 317-371.

Government of British Columbia. (2017). Social innovation. URL: http://www2.gov.bc.ca/gov/content/employment -business/business/social-innovation [September 25, 2018].

Government of Ontario. (2017). Impact: A social enterprise strategy for Ontario. URL: https://www.ontario.ca/page /impact-social-enterprise-strategy-ontario/ [September 25, 2018].

Hall, B.L. (2009). Higher education, community engagement, and the public good: Building the future of continuing education in Canada. Canadian Journal of University Continuing Education, 35(2), 11-23.

Huddart, S. (2008). New economy of engagement. Open Source Business Resource, 16-21. URL: https://search .proquest.com/docview/1695038766?accountid=14701 [March 6, 2020]

Huddart, S. (2017, April 17). Seven years on and seven years out: Revisiting "patterns, principles and practices in social innovation." The Philanthropist. URL: https://thephilanthropist.ca/2017/04/seven-years-on-and-seven-yearsout-revisiting-patterns-principles-and-practices-in-social-innovation/ [September 25, 2018].

Innovation, Science and Economic Development Canada. (2018). Post-secondary institutions strategic investment fund. URL: https://www.canada.ca/en/innovation-science-economic-development/programs/science-technologypartnerships/investment-fund.html [September 25, 2018].

Jackson, E. (2008, September). The CUE factor: Community-university engagement for social innovation. Technology Innovation Management Review. URL: http://timreview.ca/article/189 [September 25, 2018].

Jongbloed, B., Enders, J., \& Salerno, C. (2008). Higher education and its communities: Interconnections, interdependencies and a research agenda. Higher Education, 56(3), 303-324.

Juliani, D.P., Silva, A., Cunha, J., \& Benneworth, P. (2017). Universities' contributions to sustainable development's social challenge: A case study of a social innovation practice. International Journal of Social Ecology and Sustainable Development, 8(3), 379-399.

Kanani, R. (2016, May 25). Driving social innovation in higher education. Wise Initiative Education Review. URL: http://www.wise-qatar.org/social-innovation-higher-education-marina-kim-rahim-kanani [September 25, 2018].

Kloet, R.R., Hessels, L.K., Zweekhorst, M.B., Broerse, J.E., \& de Cock Buning, T. (2013). Understanding constraints in the dynamics of a research programme intended as a niche innovation. Science and Public Policy, 40(2), 206-218.

Kondo, N. (2016). Old problems, new solutions: Measuring the capacity for social innovation across the world [Report]. Economist Intelligence Unit. URL: http://www.eiuperspectives.economist.com/technology-innovation/old-problems -new-solutions-measuring-capacity-social-innovation-across-world-0 [September 25, 2018].

Lorinc, J. (2017, January 23). What are we talking about when we talk about social innovation? The Philanthropist. URL: https://thephilanthropist.ca/2017/01/what-are-we-talking-about-when-we-talk-about-social-innovation/ [September 25, 2018].

Majewski Anderson, M., Domanski, D., \& Howaldt, J. (2018). Social innovation: A chance and a challenge for higher education institutions. In J. Howaldt, C. Kaletka, A. Schroder, \& M. Zinrgiebl (Eds.), Atlas of social innovation. New practices for a better future (pp. 51-53). Dortmund, DE: Sozialforschungsstelle, TU Dortmund University. URL: https://www.socialinnovationatlas.net/fileadmin/PDF/Atlas_of_Social_Innovation.pdf [September 25, 2018].

Marginson, S. (2016). Higher education and the common good. Melbourne, AU: Melbourne University Publishing. Martin, G., Dale, A., \& Stoney, C. (2017). Social innovation labs in Canada: A preliminary analysis of the Canadian social innovation lab landscape. URL: https://changingtheconversation.ca/sites/all/files/Martin_Sociallnnovation Labs.pdf [September 25, 2018]. 


\section{Milley, Szijarto, \& Bennett (2020)}

Matheson, K. (2008, September). How universities can enable social innovation. Technology Innovation Management Review. URL: https://timreview.ca/article/188 [September 25, 2018].

McConnell Foundation. (2016). 12 lessons learned: A visual reflection on a year of learning about philanthropy and social innovation by the J.W. McConnell Family Foundation. URL: http://12lessons.mcconnellfoundation.cal [September 25, 2018].

McConnell Foundation. (2017a). The McConnell social innovation fund. URL: http://www.mcconnellfoundation.ca/de /programs/social-innovation-fund [September 25, 2018].

McConnell Foundation. (2017b). Re-Code. URL: https://re-code.ca [September 25, 2018].

McConnell Foundation. (2017c). Building social infrastructure retreat report. URL: https://re-code.ca/wp-content /uploads/2017/09/Recode_Social_Infrastructure_Retreat_Report.pdf [September 25, 2018].

McGowan, K., \& Westley, F. (2015). At the root of change: The history of social innovation. In A. Nicholls, J. Simon, \& M. Gabriel (Eds.), New frontiers in social innovation research (pp. 52-68). London, UK: Palgrave Macmillan.

Memorial University. (2018). Centre for social enterprise. URL: http://www.mun.ca/socialenterprise/ [April 10 2018]

Milley, P., \& Kovinthan, T. (2014). Examining the research base on university co-operative education in light of the neoliberal challenge to liberal education. Alberta Journal of Educational Research, 60(2), 377-402.

Milley, P., Szijarto, B., Svensson, K., \& Cousins, J.B. (2018). The evaluation of social innovation: A review and integration of the current empirical knowledge base. Evaluation, 24(2), 237-258.

Moore, M.L., \& Westley, F.R. (2011). Surmountable chasms: Networks and social innovation for resilient systems. Ecology and Society, 16(1). URL: https://www.jstor.org/stable/26268826 [March 6 2020].

Mulgan, G. (2006). The process of social innovation. Innovations, 1(2), 145-162.

Mulgan, G. (2012). The theoretical foundations of social innovation. In A. Nicholls \& A. Murdock (Eds.), Social innovation: Blurring boundaries to reconfigure markets (pp. 33-65). Basingstoke, UK: Palgrave Macmillan.

Mulgan, G., Tucker, S., Rushanara, A., \& Sanders, B. (2007). Social innovation: What it is, why it matters and how it can be accelerated. Oxford, UK: Skoll Centre for Social Entrepreneurship, Said Business School, Oxford University. URL: http://youngfoundation.org/wp-content/uploads/2012/10/Social-Innovation-what-it-is-why-it -matters-how-it-can-be-accelerated-March-2007.pdf [September 25, 2018].

Murray, R., Caulier-Grice, J., \& Mulgan, G. (2010). The open book of social innovation. London, UK: NESTA and The Young Foundation. URL: https://www.nesta.org.uk/report/the-open-book-of-social-innovation/ [September 25, 2018].

Natural Sciences and Engineering Research Council. (2019). NSERC's college and community innovation program: College and community social innovation fund. URL: http://www.nserc-crsng.gc.ca/Professors-Professeurs/RPP -PP/CCSIF-ICC_eng.asp [March 5, 2019].

NESTA. (2008). Social innovation: New approaches to transforming public services. URL: http://www.nesta.org.uk /publications/new-approaches-transforming-public-services [July 5, 2016].

NESTA. (2014). Innovation teams and labs: A practice guide. URL: http://www.nesta.org.uk/publications/innovation -teams-and-labs-practice-guide [July 9, 2016].

Nichols, N., Gaetz, S., \& Phipps, D. (2015). Generating social change through community-campus collaboration. Journal of Higher Education Outreach and Engagement, 19(3), 7-32.

Nichols N., Phipps D., Provencal, J., \& Hewitt, A. (2013). Knowledge mobilization, collaboration and social innovation: Leveraging investments in higher education. Canadian Journal of Nonprofit and Social Economy Research, 4(1), 25-42.

Nicholls, A., \& Murdock, A. (2012). The nature of social innovation. In A. Nicholls \& A. Murdock (Eds.), Social innovation: Blurring boundaries to reconfigure markets (pp. 1-30). London, UK: Palgrave Macmillan.

Patton, M.Q. (2011). Developmental evaluation: Applying complexity concepts to enhance innovation and use. New York, NY: Guilford Press. 


\section{Milley, Szijarto, \& Bennett (2020)}

Pinheiro, R., Wangenge-Ouma, G., Balbachevsky, E., \& Cai, Y. (2015). The role of higher education in society and the changing institutionalized features in higher education. In J. Huisman, H. de Boer, \& D.D. Dill (Eds.), The Palgrave international handbook of higher education policy and governance (pp. 225-242). London, UK: Palgrave Macmillan.

Pol, E., \& Ville, S. (2009). Social innovation: Buzz word or enduring term? The Journal of Socio-economics, 38(6), 878-885.

Preskill, H., \& Beer, T. (2012). Evaluating social innovation. Washington, DC: FSG and the Centre for Evaluation Innovation. URL: http://www.evaluationinnovation.org/sites/default/files/EvaluatingSociallnnovation.pdf [September $25,2018]$.

Quarter J., Mook, L., \& Armstrong, A. (2009). Understanding the social economy: A Canadian perspective. Toronto, ON: University of Toronto Press.

Rabadjieva, M., Schröder, A., \& Zirngiebl, M. (2017). Towards a typology of social innovation. In J. Howaldt, A.

Schröder, A. Butzin, \& D. Rehfeld (Eds.), Towards a general theory and typology of social innovation (pp. 98-119).

Dortmund, GR: Technische Universität Dortmund. URL: http://www.si-drive.eu/wp-content/uploads/2018/01

ISI-DRIVE-Deliverable-D1_6-Theory-Report-2017-final-20180131.pdf [March 6 2020].

Radius. (2018). Converge: Canadian lab practitioners exchange. URL: https://radiussfu.com/converge-canadian-labpractitioners-exchange/ [September 25, 2018].

Scaled Purpose Inc. (2015). Where to begin: How social innovation is emerging across Canadian campuses. URL: www.mtroyal.ca/cs/groups/public/documents/pdf/icp_pdf_wheretobegin.pdf [September 25, 2018].

SI-DRIVE. (2014). About SI-DRIVE. URL: https://www.si-drive.eu/?page_id=2 [September 25, 2018].

Smith, A., Voss, J.P., \& Grin, J. (2010). Innovation studies and sustainability transitions: The allure of the multi-level perspective and its challenges. Research Policy, 39(4), 435-448.

Social Innovation Canada. (2019). About us. URL: http://www.sicanada.org/ [March 8, 2019].

Social Innovation Exchange. (2018). About us. URL: https://www.socialinnovationexchange.org/about-us [September $25,2018]$.

Stauch, J. (2016). Leadership for social innovation: Results of a pan-Canadian study on leadership learning for social change. URL: http://www.mtroyal.ca/nonprofit/InstituteforCommunityProsperity/Research/LeadingCommunity Change/ssLINKIICP_report_leadershipforsocial [September 25, 2018].

Strandberg, C. (2017). Maximizing the capacities of advanced education institutions to build social infrastructure for Canadian communities. URL: https://mcconnellfoundation.ca/report/maximizing-the-capacities-of-advanced -education-institutions-to-build-social-infrastructure-for-canadian-communities/ [September 25, 2018].

Svensson, K., Szijarto, B., Milley, P., \& Cousins, J.B. (2018). Evaluating social innovations: Implications for evaluation design. American Journal of Evaluation, 39(4), 459-477.

Szijarto, B., Milley, P., Svensson, K., \& Cousins, J.B. (2018). On the evaluation of social innovations and social enterprises: Recognizing and integrating two solitudes in the empirical knowledge base. Evaluation and Program Planning, 66, 20-32.

The Young Foundation. (2012). Social innovation overview: A deliverable of the project: "The theoretical, empirical and policy foundations for building social innovation in Europe" (TEPSIE). European Commission - 7th Framework Programme, Brussels: European Commission, DG Research.

TEPSIE. (2014a). Social innovation theory and research: A summary of the findings from TEPSIE. The theoretical, empirical and policy foundations for building social innovation in Europe (TEPSIE). European Commission - 7th Framework Programme. Brussels, BE: European Commission, DG Research. URL: https://cordis.europa.eu/result /rcn/173251_en.html [September 25, 2018].

TEPSIE. (2014b). Building the social innovation ecosystem. The theoretical, empirical and policy foundations for building social innovation in Europe (TEPSIE). European Commission - 7th Framework Programme. Brussels, BE: European Commission, DG Research. URL: www.sigeneration.ca/wp-content/uploads/2014/12/TEPSIE-Graphic.pdf [September 25, 2018]. 


\section{Milley, Szijarto, \& Bennett (2020)}

Universities Canada. (n.d.). Member universities. URL: https://www.univcan.ca/universities/member-universities/ [September 15, 2018].

University of Guelph. (n.d.). Community engaged scholarship institute. URL: https://www.cesinstitute.ca/about-guelph -lab [September 18, 2018].

Vo, A.T., \& Christie, C.A. (2018). Where impact measurement meets evaluation: Tensions, challenges, and opportunities. American Journal of Evaluation, 39(3), 383-388.

Vorsteveld, J. (2016). Context and community: A discourse analysis of Canadian post-secondary social innovation and social entrepreneurship initiatives. URL: https://scholars.wlu.ca/cgi/viewcontent.cgi?referer=https://www.google.ca /\&httpsredir=1\&article=1020\&context=brantford_sjce [September 25, 2018].

Wallerstein, N., \& Duran, B. (2008). The theoretical, historical and practice roots of CBPR. In N. Wallerstein, B. Duran, J.G. Oetzel, \& M. Minkler (Eds.), Community based participatory research for health: Advancing social and health equity (pp. 17-30). San Francisco, CA: Jossey Bass.

Weerts, D.J., \& Sandmann, L.R. (2010). Community engagement and boundary-spanning roles at research universities. The Journal of Higher Education, 81(6), 632-657.

Westley, F. (2013, November 14). The history of social innovation. Keynote speech at NESTA Social Frontiers Conference, London. URL: https://www.nesta.org.uk/sites/default/files/key_note_speech_frances_westley_on_the _history_of_social_innovation.pdf [July 6, 2016].

Westley, F., \& Antadze, N. (2010). Making a difference: Strategies for scaling social innovation for greater impact. Innovation Journal, 15(2), 2-19.

Westley, F., \& Antadze, N. (2013). When scaling out is not enough: Strategies for system change. Paper presented at NESTA Social Frontiers Conference, London. URL: http://www.transitsocialinnovation.eu/content/original/Book\%20 covers/Local\%20PDFs/92\%20SF\%20Antadze\%20and\%20Westley\%20Scaling\%20out\%20paper\%202013.pdf [September, 25, 2018].

Westley, F., Goebey, S., \& Robinson, K. (2017). Change lab/design lab for social innovation. Annual Review of Policy Design, 5(1), 1-20.

Westley, F., Zimmerman, B., \& Patton, M.Q. (2006). Getting to maybe: How the world was changed. Toronto, ON: Random House.

White House Office of Social Innovation and Civic Participation. (2016). Office of social innovation and civic participation. URL: https://www.whitehouse.gov/administration/eop/sicp [July 4, 2018].

White, S.C., \& Glickman, T.S. (2007, Spring). Innovation in higher education: Implications for the future. New Directions for Higher Education, 137, 97-105.

\section{ABOUT THE AUTHORS / LES AUTEURS}

Peter Milley is Associate Professor in the Faculty of Education and Senior Associate of the Centre for Research on Educational and Community Services at the University of Ottawa, 145 Jean-Jacques Lussier, Ottawa K1N 6N5. Email: pmilley@uottawa.ca.

Barbara Szijarto recently received her PhD from the Faculty of Education at the University of Ottawa and is an Associate of the Centre for Research on Educational and Community Services at the University of Ottawa, 145 Jean-Jacques Lussier, Ottawa K1N 6N5. Email: barbszijarto@gmail.com.

Kristen Bennett recently received her M.Ed. from the Faculty of Education at the University of Ottawa and is working at the Public Health Agency of Canada. Email: kbram021@uottawa.ca. 